\title{
Seeder of exact seeding of seeds of cotton on the crest with drip irrigation
}

\author{
Parakhat Berdimuratov ${ }^{1 *}$, Bakhtiyar Shaymardanov ${ }^{1}$, Dilshod Ruziyev ${ }^{1}$, Abdulaziz \\ Khujakulov $^{2}$, Irina Gorlova ${ }^{1}$ and Ohunjon Usarov ${ }^{1}$ \\ ${ }^{1}$ Tashkent Institute of Irrigation and Agricultural Mechanization Engineers, Tashkent, Uzbekistan \\ ${ }^{2}$ Karshi Engineering Economic Institute, Karshi, Uzbekistan
}

\begin{abstract}
The research aims to develop a seed drill for precise seeding on a ridge with drip irrigation. The basic principles and methods of classical mechanics, mathematical analysis, and statistics were used in this study. The existing technologies of sowing cotton seeds are analyzed. The authors have developed a method of seeding the cotton on the crest with drip irrigation and drill for its implementation, including the working body for fertilizer, shaper gasket comb attached to him Coulter, sigortac for seeding, packer roller, device for laying irrigation hose, and sigortac for sealing hose soil. Combining the operations of sowing cotton seeds with the simultaneous formation of ridges, fertilizing, and drip irrigation helps to reduce labor costs and increase the yield of raw cotton. This reduces the consumption of irrigation water, simplifies the design of the irrigation hose, and increases its service life
\end{abstract}

\section{Introduction}

Success in the cultivation of crops largely depends on the timing and quality of tillage [1], sowing [1,2] and harvesting crops [3], and the latter, in turn, - on the methods of its implementation and the perfection of the design of machines [4-6]. Considerable experience has been accumulated in combining technological operations for tillage, fertilization, and sowing by using combined machines and aggregates [7-23].

Increasing the yield of cotton and harvesting it in the optimal time is associated with ensuring the production of early, friendly and healthy seedlings. However, in recent years, cotton growers in Uzbekistan during the sowing season face great difficulties due to adverse weather conditions (heavy rains, frost on the soil, etc.). Because of this, cotton has to be replanted on the part of the area, which leads to a decrease in its yield, delayed harvesting, and higher production costs. In this regard, the cotton growers of our Republic were faced with the task of changing the technology of growing cotton, which would allow for high-quality sowing at an early date, complete the harvest in October, and thus make it possible to carry out all the necessary fieldwork in full for the next year's harvest, before the onset of inclement

\footnotetext{
*Corresponding author: b parakhat@mail.ru
} 
days [28]. To avoid the impact of adverse weather conditions on cotton growth in several regions of our Republic, sowing on ridges has begun instead of sowing cotton on a smooth field [29]. With this technology, after heavy precipitation, puddles do not form over the seedbed. For the organization of sowing using this technology, it is currently necessary to cut the ridges in the fall. Before sowing to prepare their top for this work, all this entails significant labor and material costs, which dramatically reduces the effectiveness of this technology. In addition, as the experience of sowing cotton along the ridges has shown, it is very difficult to carry out it with existing sowing units since the seeder's coulter does not have the necessary support here [31].

To eliminate these shortcomings, it is necessary to develop a device for sowing cotton on the ridges, which would allow at the lowest cost to get early and healthy seedlings without replanting, and most importantly, protect these crops from rain flows and, if necessary, carry out feed irrigation.

The research aims to develop a seed drill for the precise seeding of seeds on a ridge under drip irrigation.

\section{Methods}

The basic principles and methods of classical mechanics, mathematical analysis, and statistics were used in this study.

Considering the shortcomings in the existing sowing technologies in the old irrigation zone, where seedlings can be obtained from natural moisture, and there is enough fertile soil, beds (at least $100 \mathrm{~mm}$ high) can be formed simultaneously with sowing. In this direction, special devices for the cotton seeder were developed. For example, a seed drill is known [34], its disadvantages are not straightness of sowing seeds, caused by the wagging of the coulter in the transverse direction relative to the bed due to the lack of support; the collapse of the bed during the growing season of the plant due to the lack of their compaction; lack of targeted fertilizer application.

The study's objectives are to achieve the straightness of seed sowing, the formation of a compacted bed directly during sowing with simultaneous targeted application of fertilizer for seeds, laying and sealing of irrigation hoses on the ridge of the bed.

The tasks are achieved $[17,18]$ by rigid mounting opener to shaper-seal, picking device planter fertilizer, and packer hose drip irrigation improved the indicator of sustainable irrigation, increase of service life of the irrigation hose and using water outlet hose with the soil to reduce pressure jet of irrigation water.

The essence of the method $[33,34]$ is that the seeds are sown on the ridge of the bed above the layer of mineral fertilizers applied simultaneously with sowing, the beds are formed directly during sowing with soil compaction, and watering is carried out using drip irrigation hoses laid on the ridge of the beds in specially pressed and filled with soil recesses.

\section{Results and Discussion}

Planter for the implementation of the proposed method consists of consecutive working on 1 fertilizer, capacity 2 for fertilizers, tool provider 3, driver of the seal of a bed consisting of a visor 4 , block 5, having the form of a mirror installed skimmers, with the output of a trapezoid. The visor 4 , smoothly passes into the upper roof 6 . The side flaps and the housing cover gradually narrow. The coulter 7 is rigidly connected to the shaper-sealer, which ensures straightness of seeding by eliminating the influence of the coulter relative to the shaper-sealer. Sock is installed on the seed Bank 8, behind him is sigortac 9 for seeding, 
skating rink 10 and device for laying of irrigation hose, including drum for winding 11 of 12 hose, guide rollers 13, 14 presser rink, and sigortac 15 for termination of the laid hose, 16 seeds are made on fertilizers 17.

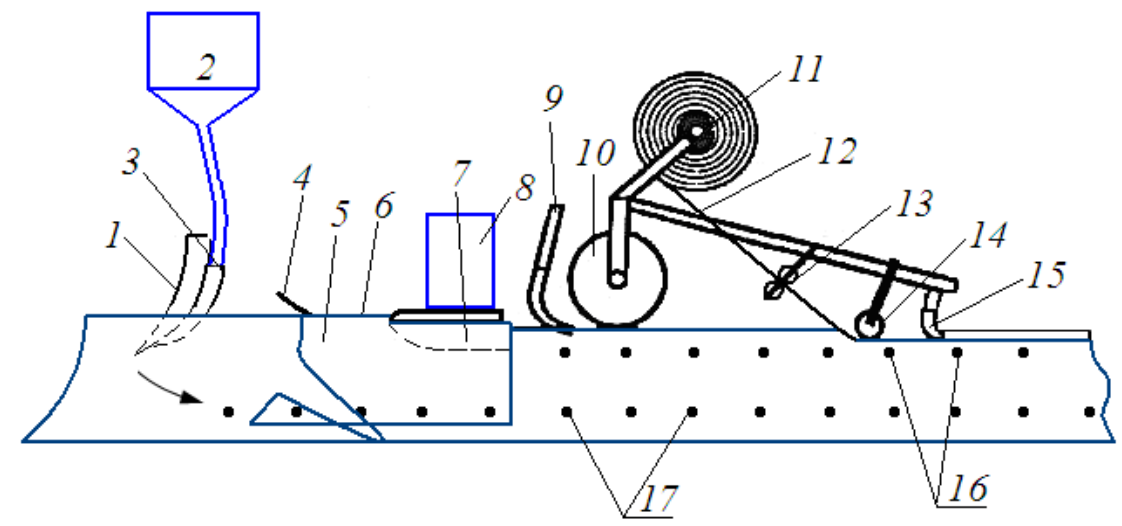

Fig. 1. Planter layout

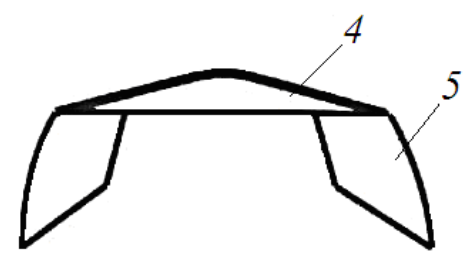

Fig 2. Diagram of the shaper

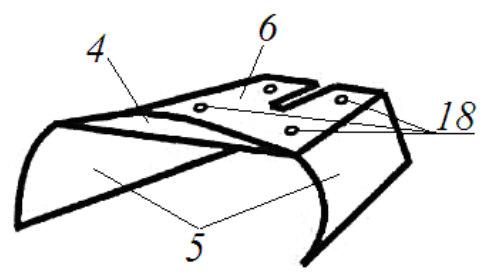

Fig. 3. Mounting diagram

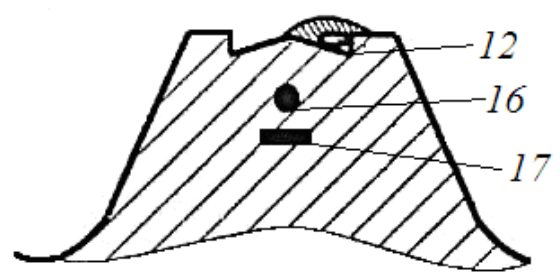

Fig. 4. The scheme of the ridge with the location of the irrigation hose, seeds, and fertilizers.

Figure 2 shows the front view of the bed sealer, Fig. 3 shows the sealer in isotherm with holes 18 for the bolts of the rigid attachment of the coulter to the shaper.

The technological process of the seeder and the functional tasks of its elements are as follows.

With the forward movement of the seeder, the working body 1 introduces mineral 
fertilizers into the soil, the dumps of the shaper-sealer 5 are raked, compressed in the horizontal direction of the pre-treated (harrowing, not enough, etc.) soil and give it a given shape. Due to the narrowing of the cross-section of the shaper body, the beds are pressed to a given value of the soil density.

As with a traditional planter, Coulter 7, sow the seeds on the crest of the garden, buried seeds the earthing devices 8,9 packer roller compacts the soil over the seeds sown to ensure reliable contact of seeds with the soil and on the crest of the ridges pushes deeper under laying irrigation hose drip irrigation. In these recesses, the irrigation hose 12 is laid, winding it from the drum 11, passing through the guide rollers 13 and the rolling roller 14, and the earthing devices 15 fill the hose with a layer of soil. Thus, in one pass of the seeder, the entire work cycle is provided for creating a compacted bed, local and targeted fertilization 17, sowing seeds 16 , and laying the irrigation hose.

The cross-section of the bed after the passage of the seeder with the sown seeds 16 , the introduction of fertilizer 17, and the laid irrigation hose are shown in Figure 4.

The advantages of drip irrigation (saving irrigation water, fertilizers, reducing the cost of weed control) are well known. The method is widely used on a global scale, mainly in the plantation cultivation of agricultural crops. The objective of the design of the irrigation hose is to improve the stability of irrigation and increase the service life of the irrigation hose.

In the design of the irrigation hose made of elastic plastic, the water outlets are arranged in a single line on one side of the irrigation hose with flanging at the edges of the holes to give them strength against breaks at the edges of the holes. Water outlets are round holes; the ratio of their holes to the diameter of the irrigation hose is $d / D=1 /(30-40)$; the holes are made in the wall on one side of the hose at a distance of $L=80-400 \mathrm{~mm}$.

Figure 5 shows a cross-section of the hose 2, filled with water 8 and a water outlet 3 , at the edges of which a flanging 4 is made.

As you can see, the irrigation hose has a relatively simple design; the ratio of the diameter of the holes to the diameter of the hose 1/ (30-40) allows you to ensure a uniform flow of water along the irrigation hose at a low head. Because the water-filled hose is located with water outlets down, the irrigation water jet due to the resistance of the soil reduces the pressure, and the irrigation effect is adequate for watering drops, that is, the soil in contact with the dropper compensates for the pressure of the jet.

The closest analogue of the laying method is the invention (SU1634957).

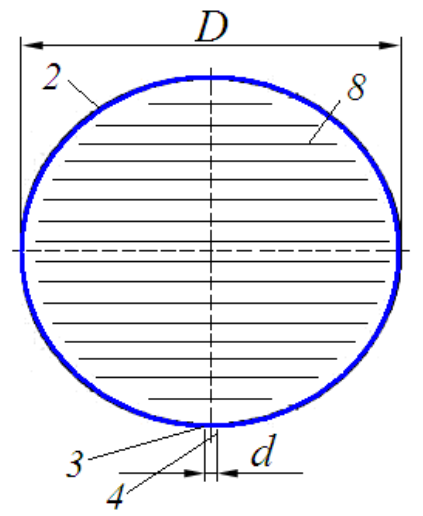

Fig. 5. Irrigation hose design 


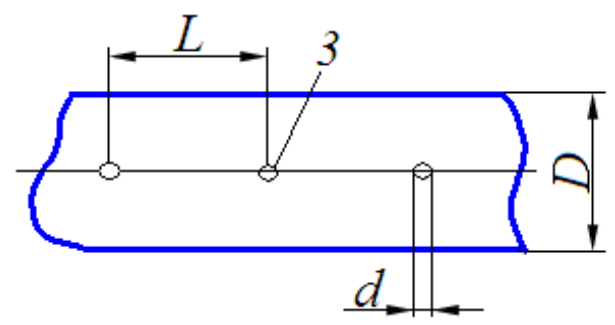

Fig. 6. Layout of the water outlets on the hose segment

According to the analog, a perforated irrigation hose is placed on the surface of a pipeline laid in a trench. When the pipeline is filled with water, the hose is brought to the surface of the field for irrigation.

The disadvantage of the analog is the complexity of the system and the overspending of irrigation water since irrigation is carried out by jet, not drip.

The task of the method of laying the irrigation hose is the contact of the water outlets. As a result, the soil, due to direct contact with the water outlet, acts as a pressure compensator for the water jet, and a thin layer of soil on top of the hose protects it from sunlight, thereby extending its service life.

The irrigation hose is placed on the ridge of the bed for drip irrigation with water outlets on the soil surface and covered with a layer of soil; the angle of deviation from the axis of the water outlet to the soil surface should not exceed 150 .

The best option for laying a hose is to lay with the arrangement of water outlets along the normal (perpendicular) to the soil surface. However, experiments [29] conducted Yangiyul district, at the site of the State centre for certification and testing of agricultural machinery and technologies under the Cabinet of Ministers of the Republic of Uzbekistan showed that the overflow contact with the soil (due to the deformations of the soil and the pipe) is achieved when inclining the axis of the outlet to the soil surface 150 . In the experiments, we used a water pump of the GRANDFAR-1 type with a capacity of 30 cubic meters per hour per hectare. Local manufacturers make all irrigation hoses. Irrigation hoses are elastic, have a thickness of 250-300 microns, a certain diameter, and size of the hole for irrigation; when watering, the hose expands in diameter, and in the absence - narrows, and thus self-cleaning occurs from the Elijah layers inside the hoses. The length of the irrigation hoses is from 100 to 250 meters, the distance between the holes is from 7 to $10 \mathrm{~cm}$. According to this method, watering can be organized immediately after sowing as according to agricultural technology. In studies, it was determined [29] that the water flow rate for furrow surface irrigation was $6000 \mathrm{~m} 3$, and for the proposed irrigation method on the ridge $-2000 \mathrm{~m} 3$. Opening of irrigation furrows, manual thinning was not performed.

Laying irrigation hose shown in figure 7 , which schematically shows a cross-section of 1 beds, irrigation hose 2, outlet 3, track 5 from the compactor planters, the layer of soil 6 to cover the hose from the solar radiation, the contour of the 7 areas of moisture, the root system of plants 8 , the angle $\alpha$ is the deviation of the axis of the outlet to the soil surface.

The irrigation hose is laid out in the field along the rows of the plant on the ridge of the bed along the track of the figured rewinding drum of the seeder with water outlets down. One end of the hose is hermetically sealed, and the other is connected to a source of irrigation water with a pressure (0,1-0,3 atm.). Water entering the hose fills it and flows out through the holes. Meeting the resistance of the soil reduces the pressure, providing irrigation in a similar way to watering with drops. Thus, the soil serves as a jet pressure compensator. 


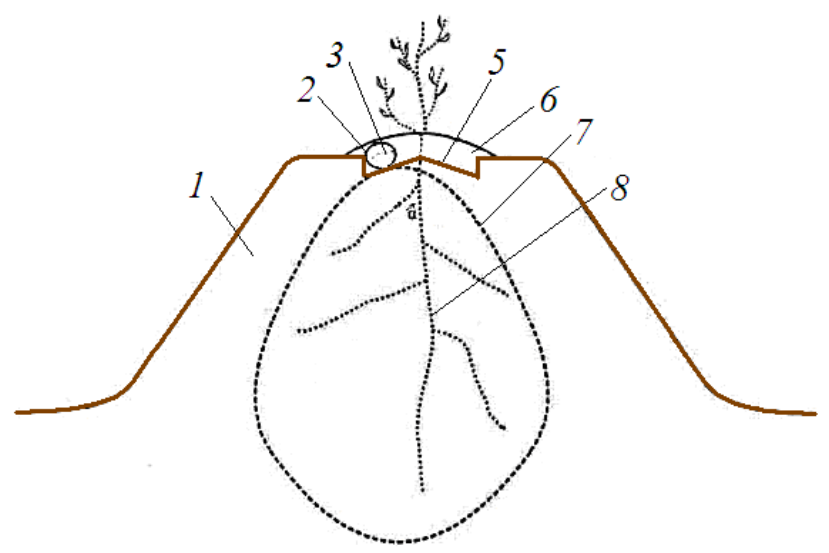

Fig. 3. Installation diagram of the irrigation hose

\section{Conclusions}

1. Combining the operations of sowing cotton seeds with the simultaneous formation of ridges, fertilizing, and drip irrigation helps to reduce labor costs and increase the yield of raw cotton.

2. Implementing the proposed method of sowing cotton seeds will allow, along with saving irrigation water and fertilizers, to significantly simplify the design of the irrigation hose and increase its service life.

3. Planter to combine the operations of sowing seeds of cotton with the simultaneous formation of ridges, fertilizer and drip irrigation should consist of the working body for fertilizer, driver of the seal of the comb opener, rear roller, device for laying irrigation hose, and sigortada for sealing hose soil.

\section{References}

1. Mamatov, F., Mirzaev, B., Shoumarova, M., Berdimuratov, P., Khodzhaev, D. Comb former parameters for a cotton seeder// International Journal of Engineering and Advanced Technology (IJEAT) Volume-9 Issue1 October/ DOI: 10.35940/ijeat.A2932.109119.

2. Mamatov, F., Mirzaev, B., Berdimuratov, P., Turkmenov, Kh., Muratov, L., Eshchanova, G. The stability stroke of cotton seeder moulder // CONMECHYDRO 2020. IOP Conf. Series: Materials Science and Engineering 883 (2020) 012145 IOP Publishing. doi:10.1088/1757-899X/883/1/012145.

3. Mamatov, F.M., Eshdavlatov, E., Suyunov, A. The Shape of the Mixing Chamber of the Continuous Mixer // Jour of Adv Research in Dynamical \& Control Systems, Vol. 12, 07-Special Issue, 2020. DOI: 10.5373/JARDCS/V12SP7/20202318 ISSN 1943$023 \mathrm{X}$.

4. Mamatov, F., Ergashev, I., Ochilov, S., Pardaev, X. Traction Resistance of Soil Submersibility Type "Paraplau" // Jour of Adv Research in Dynamical \& Control Systems, Vol.12, 07-Special Issue, 2020. DOI: 10.5373/JARDCS/V12SP7/20202336 ISSN1943-023X.

5. Aldoshin, N., Mamatov, F., Ismailov, I., Ergashov, G. Development of combined tillage tool for melon cultivation // 19th international scientific conference engineering for rural development Proceedings, Jelgava, 20.-22.05.2020. Volume 19. ISSN 16915976. DOI:10.22616/ERDev.2020.19.TF175. 
6. Umurzakov, U., Mirzaev, B., Mamatov, F., Ravshanov, H., Kurbonov, S. A rationale of broach-plow's parameters of the ridge-stepped ploughing of slopes // XII International Scientific Conference on Agricultural Machinery Industry IOP Conf. Series: Earth and Environmental Science 403(2019) 012163 IOP Publishing doi:10.1088/1755-1315/403/1/012163.

7. Mirzaev, B., Mamatov, F., Chuyanov, D., Ravshanov, X., Shodmonov, G., Tavashov, $\mathrm{R}$ and Fayzullayev, X. Combined machine for preparing soil for cropping of melons and gourds // XII International Scientific Conference on Agricultural Machinery Industry. doi.org/10.1088/1755-1315/403/1/012158.

8. Mirzaev, B., Mamatov, F., Ergashev, I., Ravshanov, H., Mirzaxodjaev, Sh., Kurbanov, Sh., Kodirov, U and Ergashev, G. Effect of fragmentation and pacing at spot ploughing on dry soils // E3S Web of Conferences 97. doi.org/10.1051/e3sconf/201913501065.

9. Mamatov, F., Mirzaev, B., Batirov, Z., Toshtemirov, S., Tursunov, O., Bobojonov, L. Justification of machine parameters for ridge forming with simultaneous application of fertilizers // CONMECHYDRO - 2020 IOP Conf. Series: Materials Science and Engineering 883(2020) 012165 IOP Publishing. doi:10.1088/1757899X/883/1/012165.

10. Mirzaev, B., Mamatov, F., Avazov, I., Mardonov, S. Technologies and technical means for anti-erosion differentiated soil treatment system // E3S Web of Conferences. doi.org/10.1051/e3sconf/20199705036.

11. Aldoshin, N., Didmanidze, O., Mirzayev, B., Mamatov, F. Harvesting of mixed crops by axial rotary combines // Proceeding of $7^{\text {th }}$ International Conference on Trends in Agricultural Engineering 2019. $17^{\text {th }}-20^{\text {th }}$ Prague, Czech Republic. - pp.20-26. September (2019).

12. Mirzaev, B., Mamatov, F., Aldoshin, N and Amonov, M. Anti-erosion two-stage tillage by ripper// Proceeding of 7th International Conference on Trends in Agricultural Engineering 17th-20th. Prague, Czech Republic. - pp.391-396. September (2019).

13. Mirzaev, B., Mamatov, F., Ergashev, I., Islomov, Yo., Toshtemirov, B., Tursunov O. Restoring degraded rangelands in Uzbekistan // Procedia Environmental Science, № 6. - pp 395-404. (2019).

14. Uzakov, Z.U., Mamatov, F.M., Begulov, O. Implementation of object-oriented Programming technology in the one-dimensional oil displacement problem // International Conference on information Science and Communications Technologies: ICISCT 2019/0012008. Tashkent, Uzbekistan. INSPEC Accession Number: 19412491. DOI: 10.1109/ICISCT47635.2019.9012008.

15. Mamatov, F., Mirzaev, B., Tursunov, O. A Justification of Broach-Plow's Parameters of the Ridge-Stepped Ploughing // E3S Web of Conferences 97, 05035 (2019). doi.org/10.1051/e3sconf/20199705035.

16. Ahmedov, B.J., Mirzaev, B.S.,Mamatov, F.M., Khodzhaev, D.A., Julliev, M.K. Integrating of gis and gps for ionospheric perturbations in d- And f-layers using vlf receiver // InterCarto, InterGIS 26, - c. 547-560. DOI: 10.35595/2414-9179-2020-126-547-560.

17. Mamatov, F., Mirzaev, B., Tursunov, O., Ochilov, S and Chorieva, D. Relief, physicomechanical and technological properties of soil in the cotton growing area // ICECAE 2020. IOP Conf. Series: Earth and Environmental Science 614(2020) 012169. IOP Publishing. doi:10.1088/1755-1315/614/1/012169.

18. Shamsutdinov, Z., Ubaydullaev, Sh., Shamsutdinov, N., Mirzaev, B., Mamatov, F., and Chorshabiyev, N. The concept of the phytogenic field: theory, research experience and practical significance // ICECAE 2020. IOP Conf. Series: Earth and 
Environmental Science 614(2020) 012164. IOP Publishing. doi:10.1088/17551315/614/1/012164.

19. Umurzakov, U., Mamatov, F., Aldoshin, N., and Mirzaev, B. Exploration of tillage technologies in the Republic of Uzbekistan // ICECAE 2020 IOP Conf. Series: Earth and Environmental Science 614(2020) 012168. IOP Publishing. doi:10.1088/1755$1315 / 614 / 1 / 012168$.

20. Mamatov, F., Aldoshin, N., Mirzaev, B., Ravshanov, H., Kurbanov, Sh and Rashidov, N. Development of a frontal plow for smooth, furless plowing with cutoffs // IPICSE 2020. IOP Conf. Series: Materials Science and Engineering 1030 (2021) 012135 IOP Publishing. doi:10.1088/1757-899X/1030/1/012135.

21. Mamatov, F., Mirzaev, B., Mirzahodzhaev, Sh., Uzakov, Z and Choriyeva, D. Development of a front plow with active and passive working bodies // IPICSE 2020. IOP Conf. Series: Materials Science and Engineering 1030 (2021) 012164. IOP Publishing. doi:10.1088/1757-899X/1030/1/012164.

22. Mamato, F.M., Eshdavlatov, E., Suyuno, A. Continuous Feed Mixer Performance //Journal of Advanced Research in Dynamical and Control Systems (JARDCS). Volume-12, 07-Spesia1 Issue, 2020. DOI: 10.5373/JARDCS/V12SP7/20202343. ISSN 1943-023X.

23. Mamatov, F., Ergashev, I., Mirzaev, B., Pardaev, X, Chorieva, D. Research of the Penetration Process of the Frontal Plow // 2nd Bukittinggi International Conference on Education (BICED) 2020. Journal of Physics: Conference Series 1779 (2021) 012002. IOP Publishing. doi:10.1088/1742-6596/1779/1/012002.

24. Kodirov, U., Aldoshin, N., Ubaydullayev, Sh., Sharipov, E., Muqimov, Z and Tulaganov, B. The soil preparation machine for seeding potatoes on comb // CONMECHYDRO - 2020 IOP Conf. Series: Materials Science and Engineering 883(2020) 012143 IOP Publishing doi:10.1088/1757-899X/883/1/012143.

25. Ravshanov, Kh., Fayzullaev, Kh., Ismoilov, I., Irgashev, D., Mamatov, S. The machine for the preparation of the soil in sowing of plow crops under film // CONMECHYDRO - 2020 IOP Conf. Series: Materials Science and Engineering 883(2020) 012138 IOP Publishing doi:10.1088/1757-899X/883/1/012138.

26. Ravshanov, H, Babajanov, L, Kuziev, Sh, Rashidov, N, Kurbanov, Sh. Plough hitch parameters for smooth tails// CONMECHYDRO - 2020 IOP Conf. Series: Materials Science and Engineering 883(2020) 012139 IOP Publishing doi:10.1088/1757899X/883/1/012139.

27. Chuyanov, D., Shodmonov, G.,Avazov, I., Rashidov, N, Ochilov, S. Soil preparation machine parameters for the cultivation of cucurbitaceous crops // CONMECHYDRO - 2020 IOP Conf. Series: Materials Science and Engineering 883(2020) 012139 IOP Publishing doi:10.1088/1757-899X/883/1/012122.

28. Kalinin A.B., Ruzh'ev V.A., Teplinskij I.Z. Mirovye tendencii i sovremennye tehnicheskie sistemy dlja vozdelyvanija kartofelja: uchebnoe posobie. - SPb. -p. 160. Prospekt Nauki, (2016).

29. Shajmardanov B.P., Shajmardanov H.B., Matchanov R.D.i dr. Polivnoj shlang dlja kapel'nogo oroshenija i sposob ego ukladki. Patent UZ IAP 06314. 14.10.2020. (21). № IAP 20170013 № (22). 12.01.2017.

30. Shajmardanov B.P., Shajmardanov H..B. va bоshқ. Sejalka dlja poseva na grjadkah. Patent UZ IAP 06312. 14.10.2020. (21). № IAP 20160324 № (22). (2016).

31. Serikbaev B.S., Butajarov A.T. Raschet rezhima kapel'nogo oroshenija hlopchatnika novogo sorta «Sultan», Irrigation and Land Reclamation journal, №2 (16). pp. 10-14. Toshkent, (2019). 